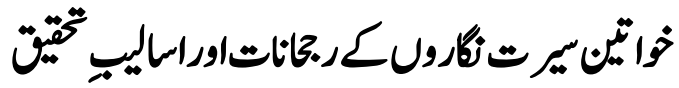

\section{The Research Methodology \& Trends in Female Seerah Writer}

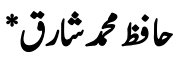 \\ مركمنورين
}

\begin{abstract}
Prophet Muhammad peace be upon him, is a role model for all mankind. In every domain of life, one may find the best shining example to follow. For this reason, it has always been an extremely important practice of Muslim Scholars to write prophetic biography. Many Muslim scholars have contributed by means of books of Seerah (Biography) and provided guidance in connection with modern challenges and conditions. Most of the known writers are male, however there are many female writers in the contemporary world who have been engaged in contributing to Biographical Studies.
\end{abstract}

The article is an effort to analyze the contemporary work on Seerah done by the women scholars. We aim to examine the features, research methodology and the trends in the work done on the Prophetic Biography.

Key Words: Seerah, Prophetic Biography, Muslim female authors

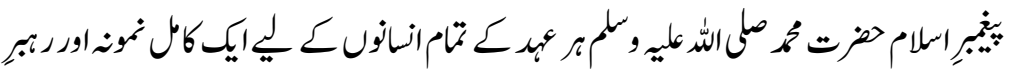

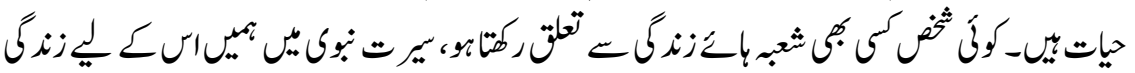

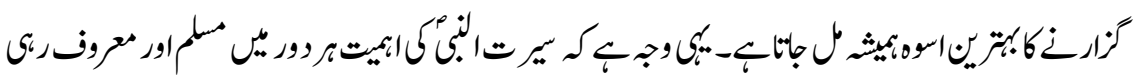

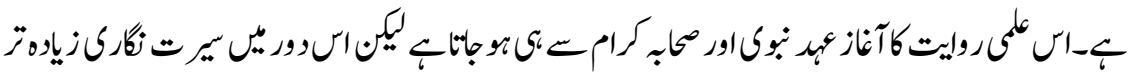

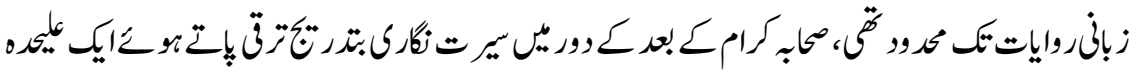

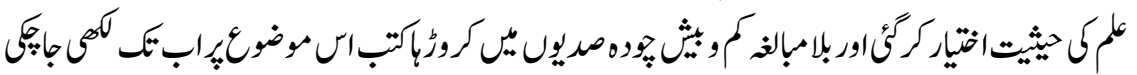

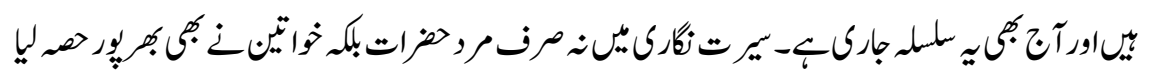

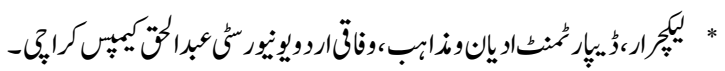

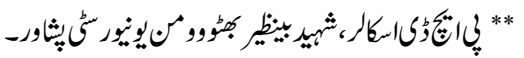




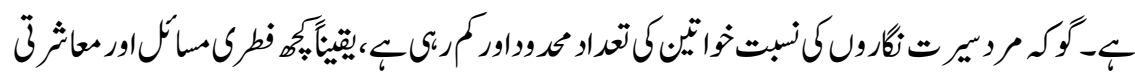

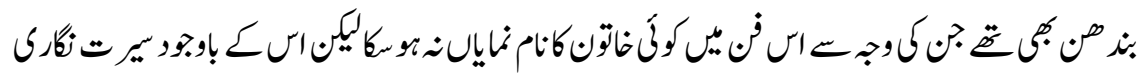

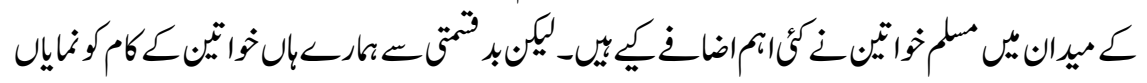

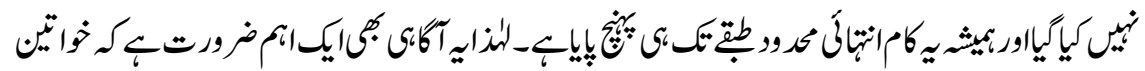

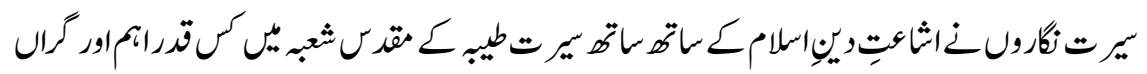

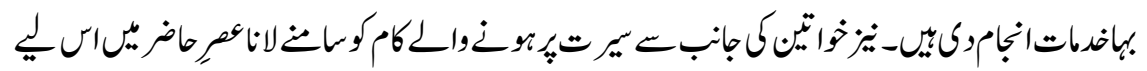

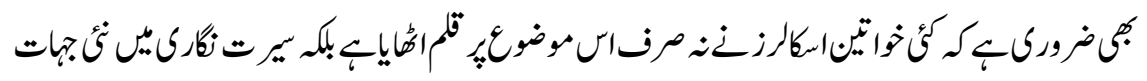

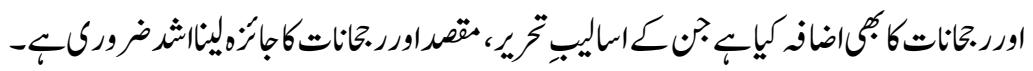

\section{ميرتع لنوكوامطلاح مثن}

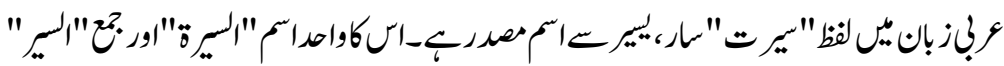

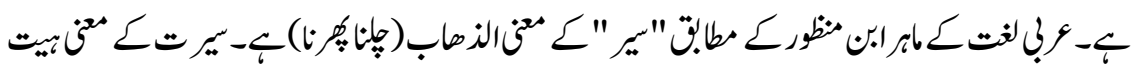

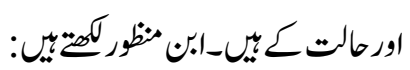

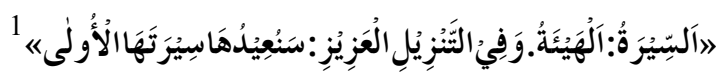

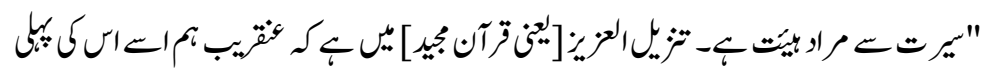

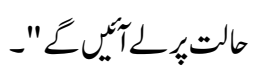

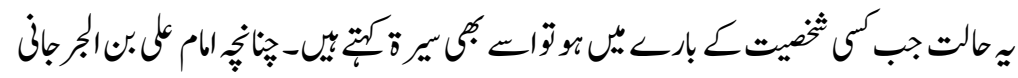

ك

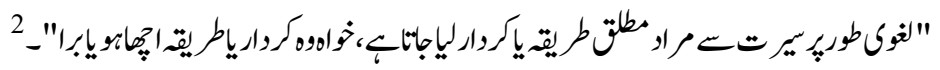

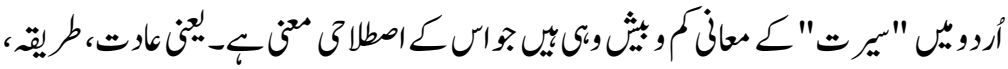

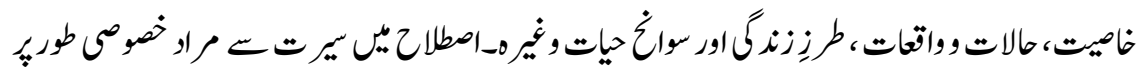

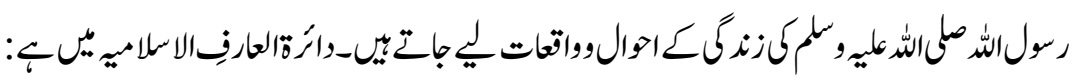

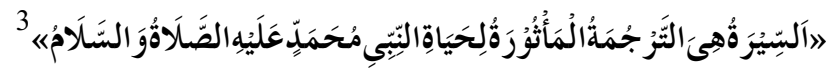

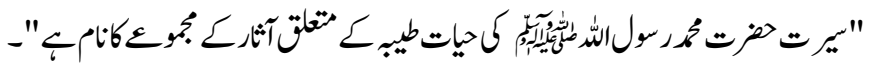




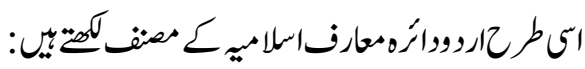

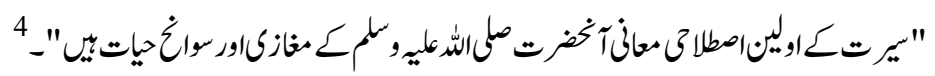

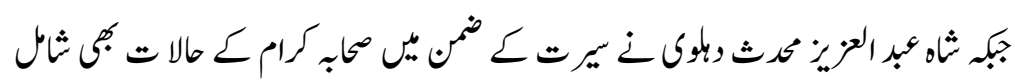

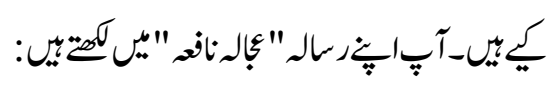

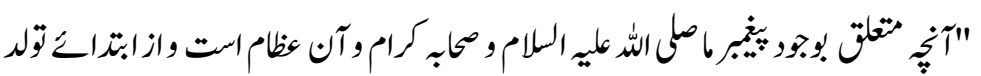

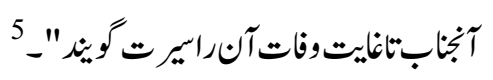

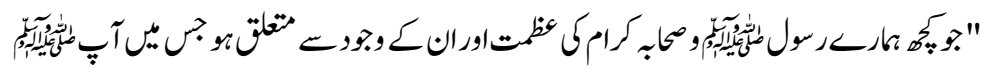

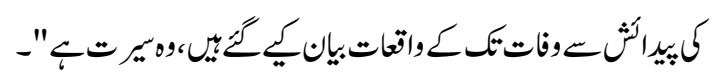

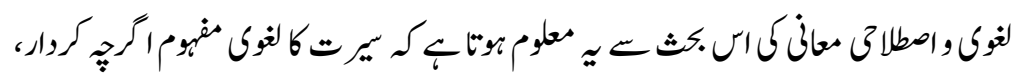

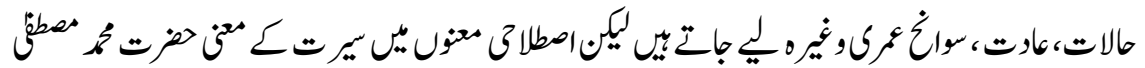

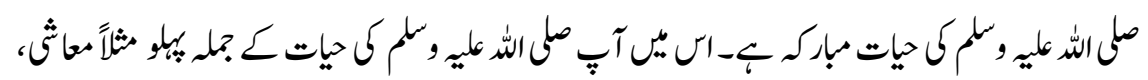

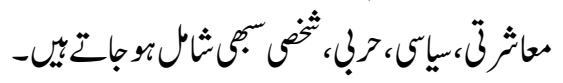

\section{ميرت نكاركايميت}

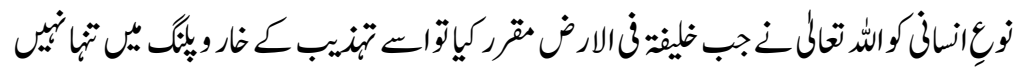

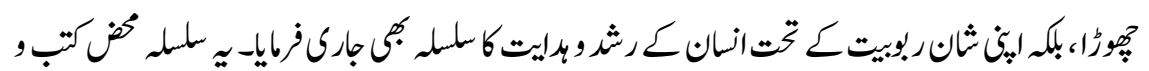

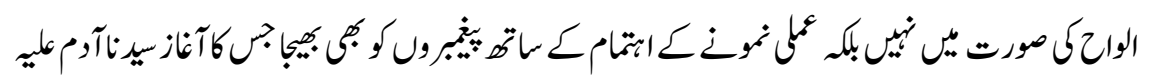

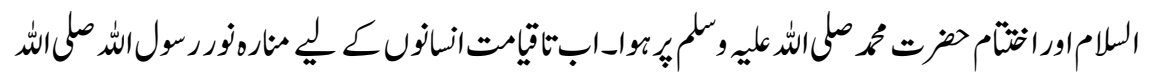

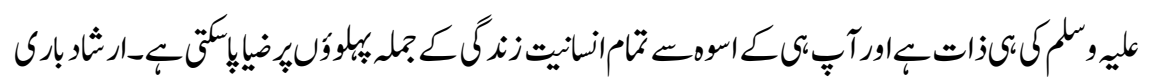
تحالظب:

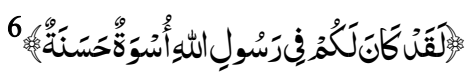

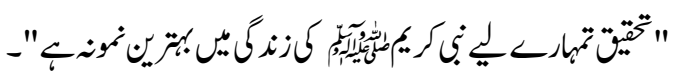




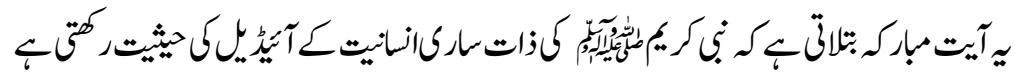

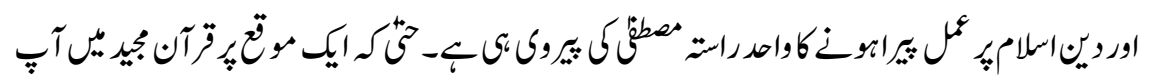

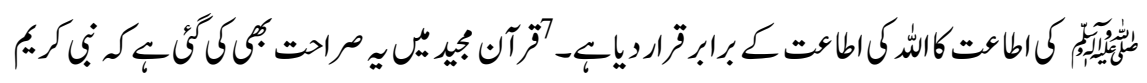

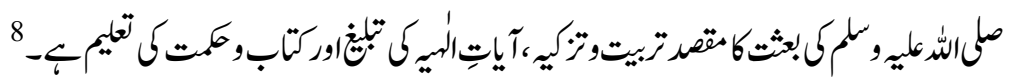

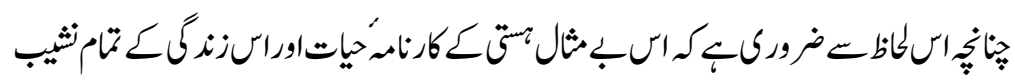

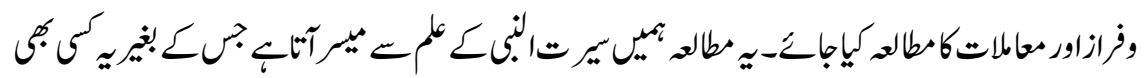

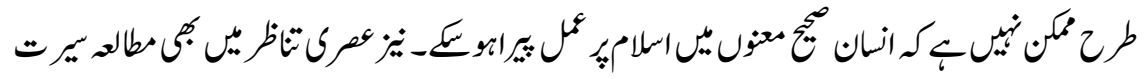

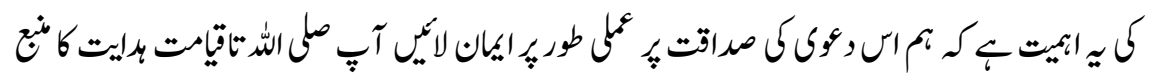

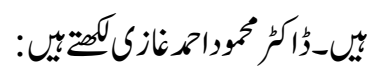

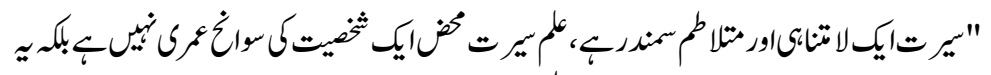

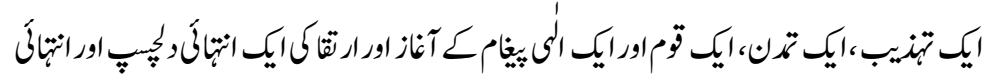

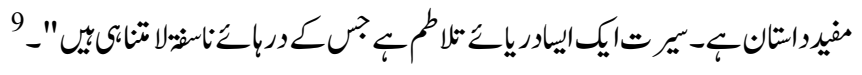

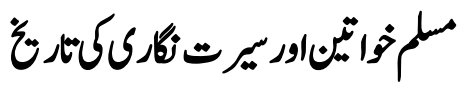

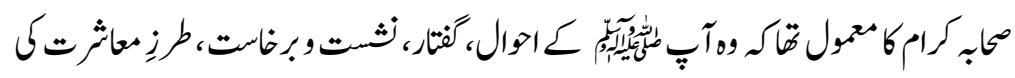

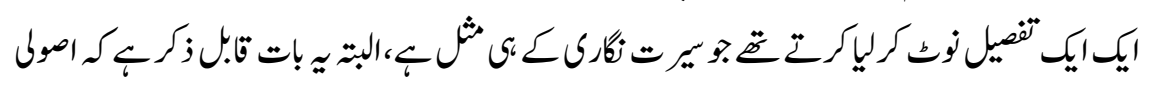

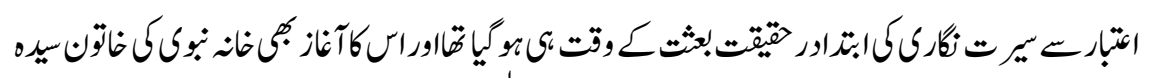

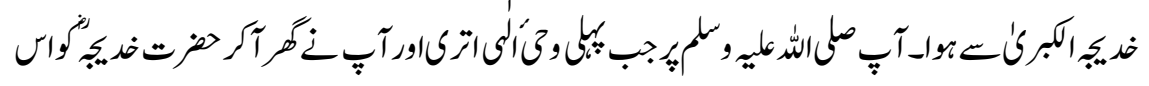

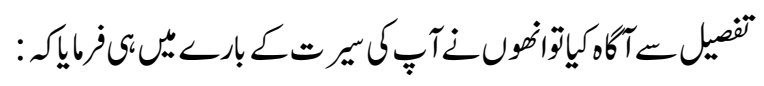

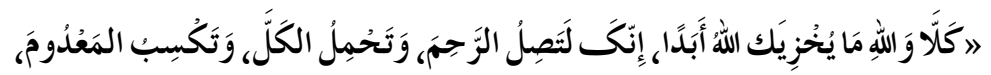

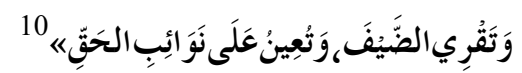

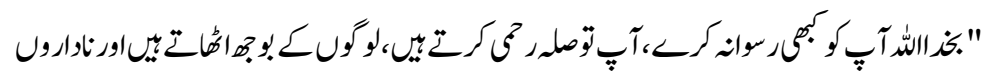

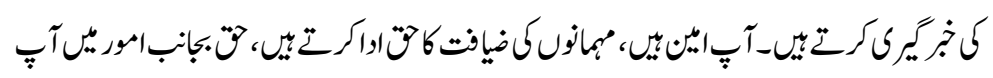

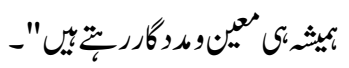




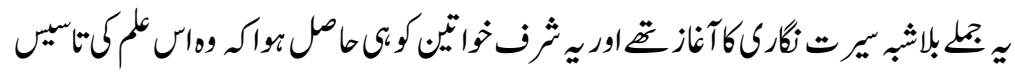

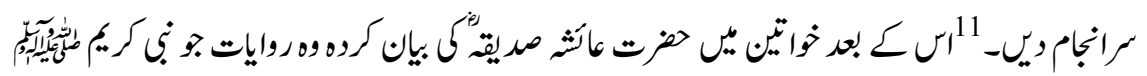

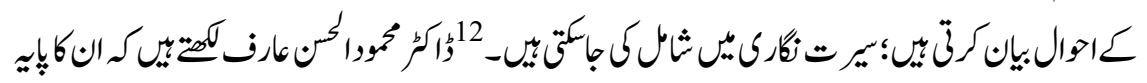

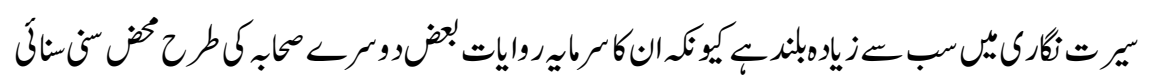

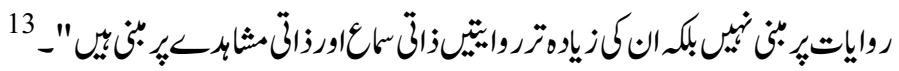

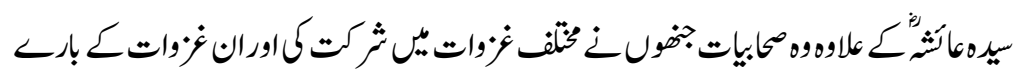

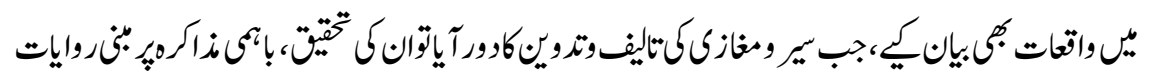

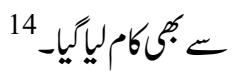

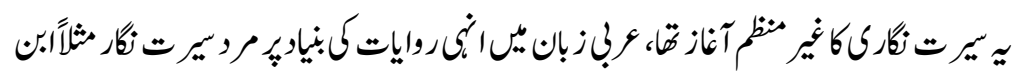

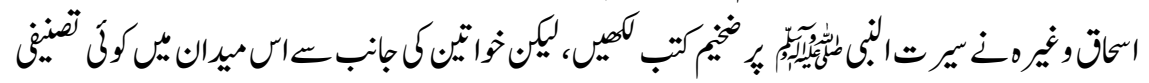

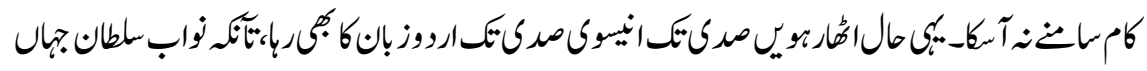

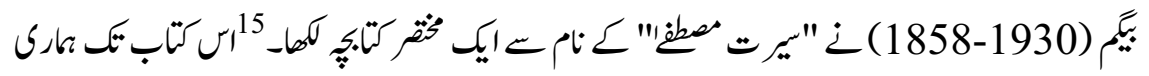

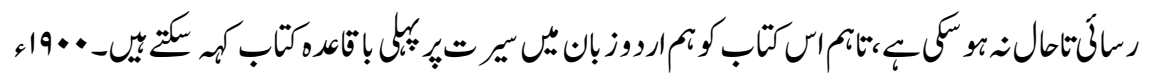

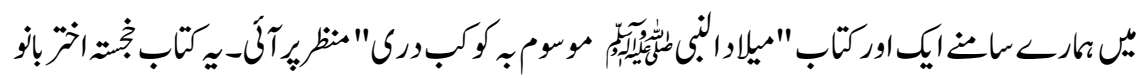

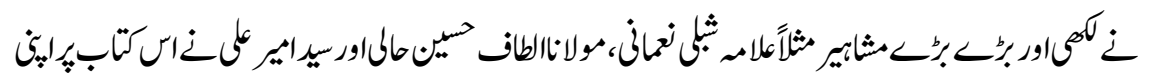

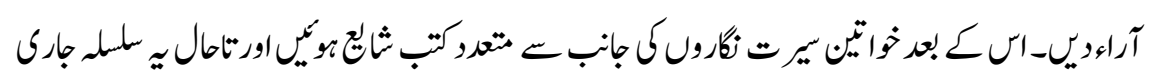

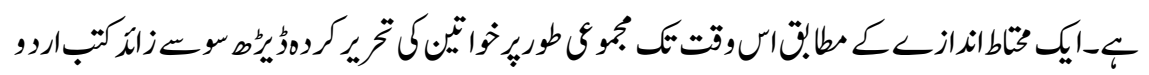

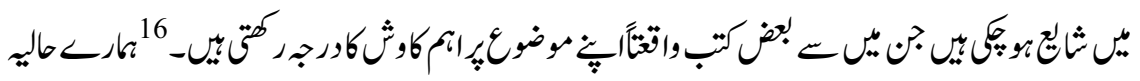

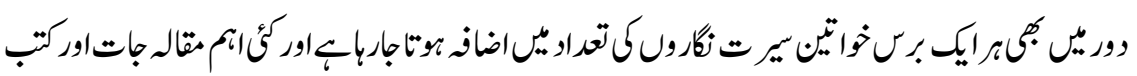

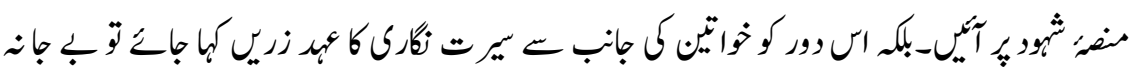

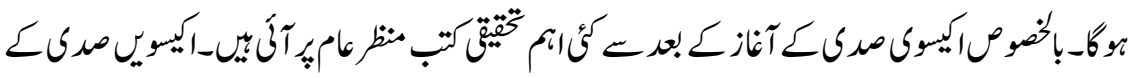

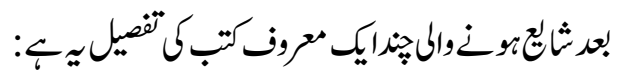


جورك-جون2020

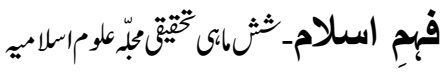

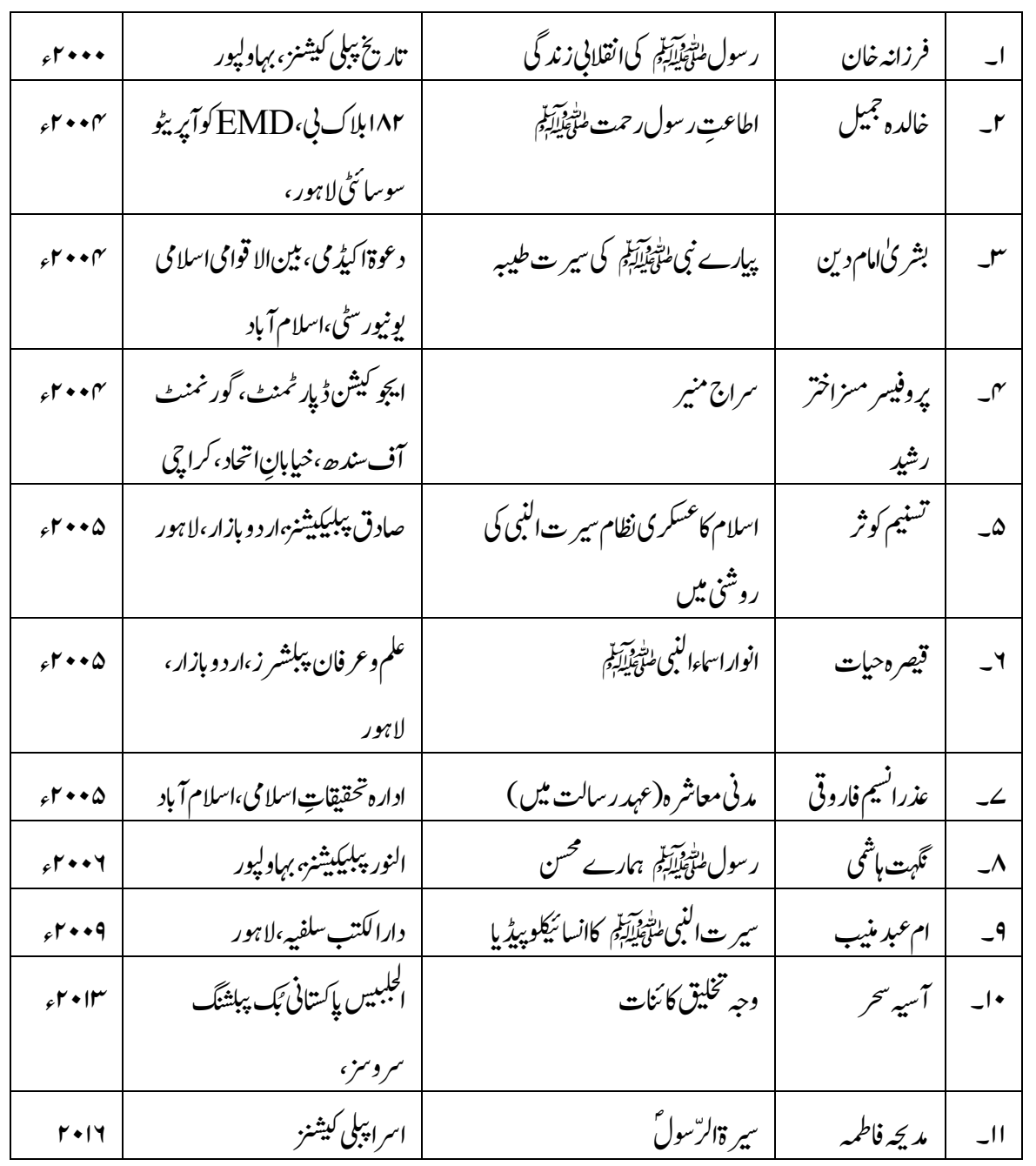

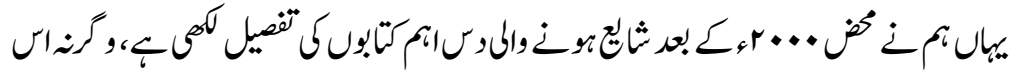

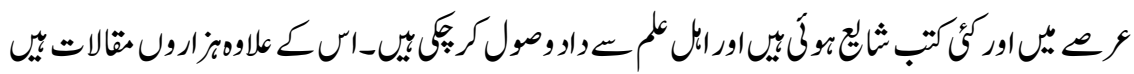

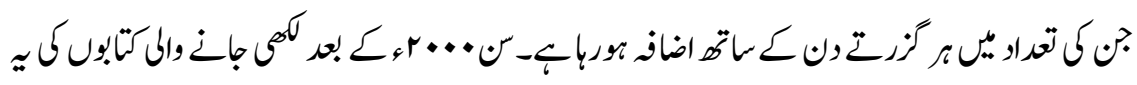

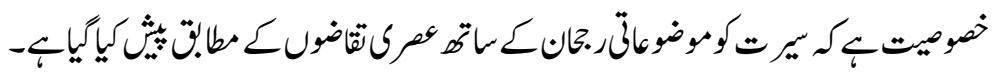

126 


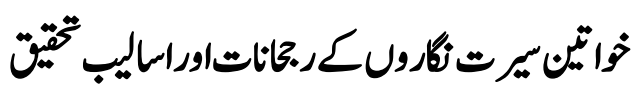

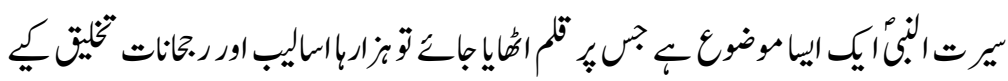

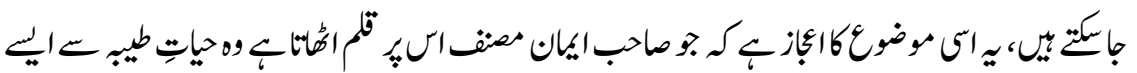

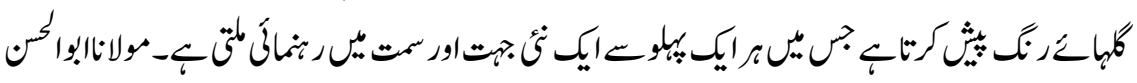

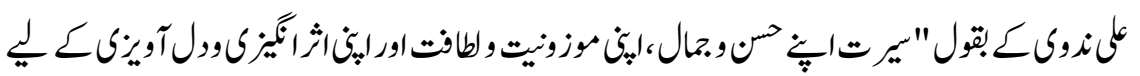

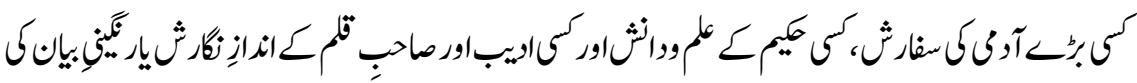

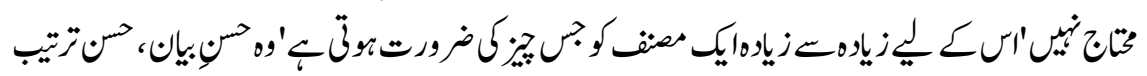

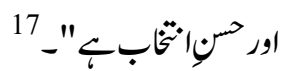

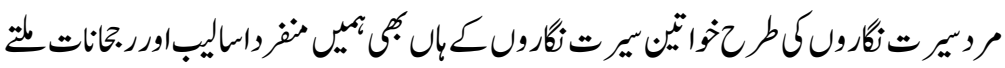

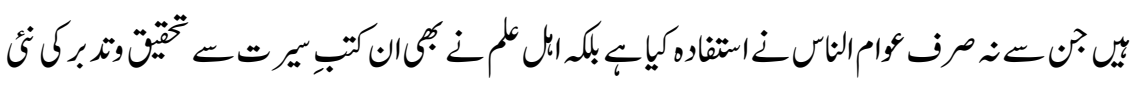

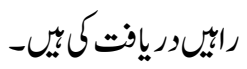

\section{اسايب تخقنّ}

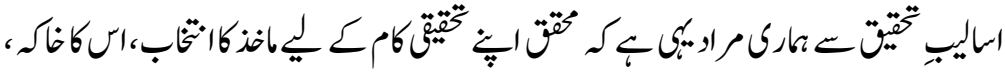

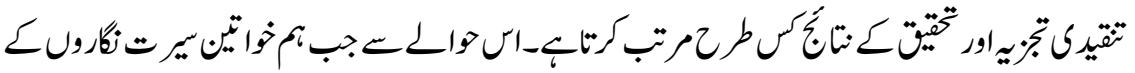

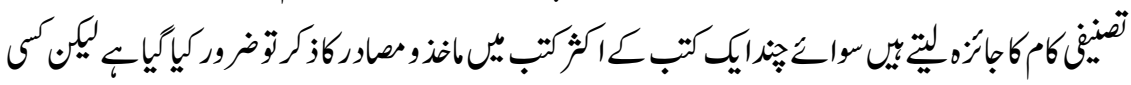

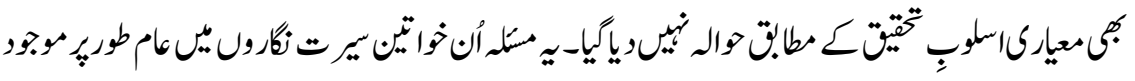

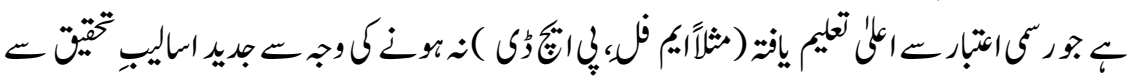

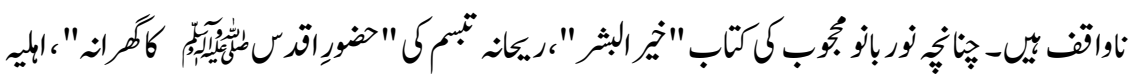

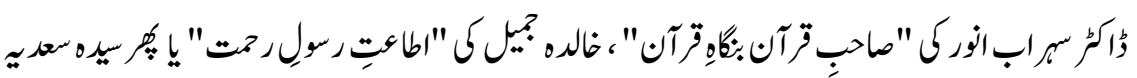

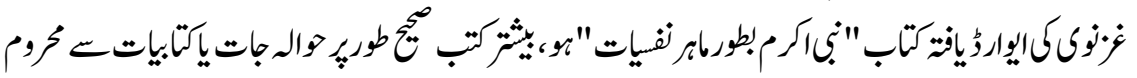

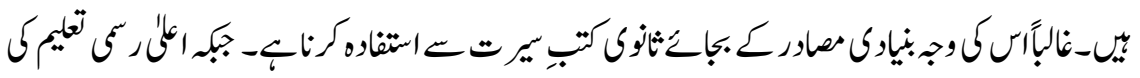

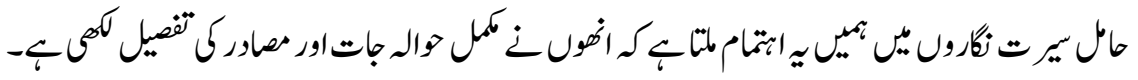




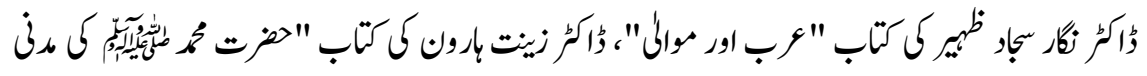

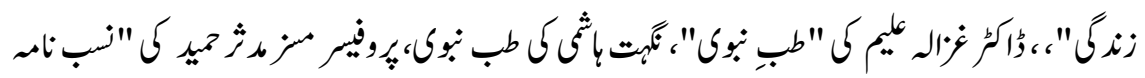

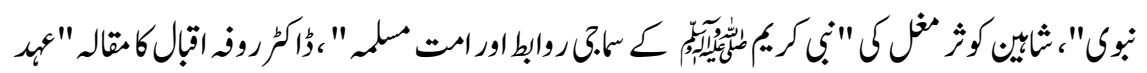

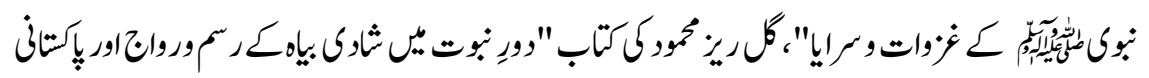

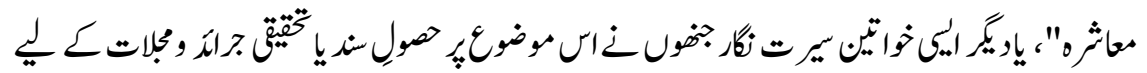

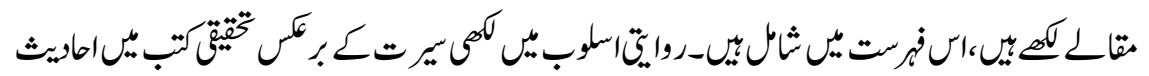

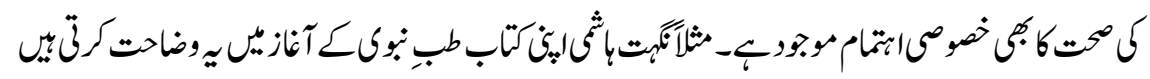

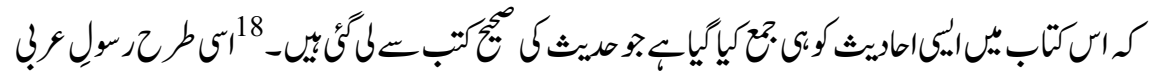

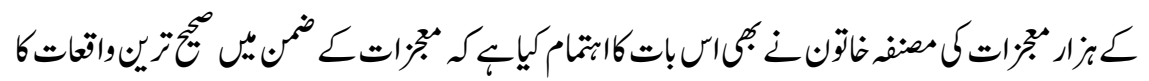

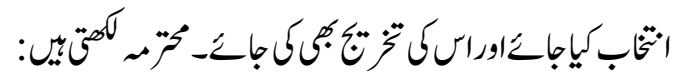

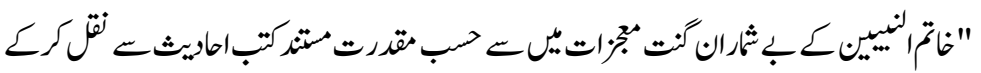

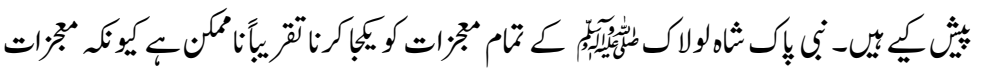

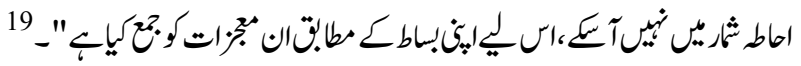

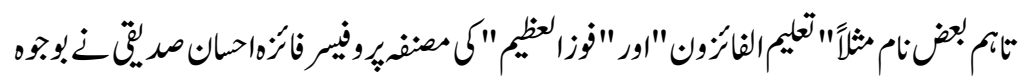

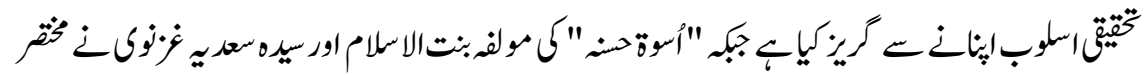

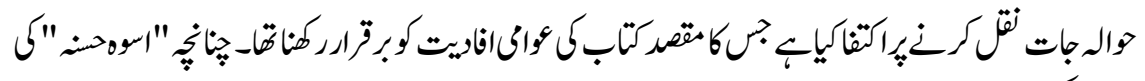

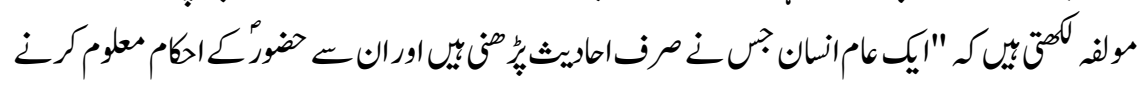

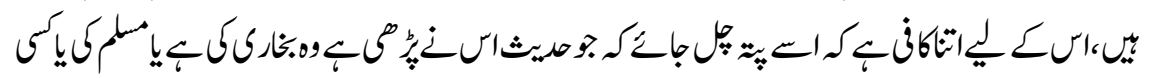

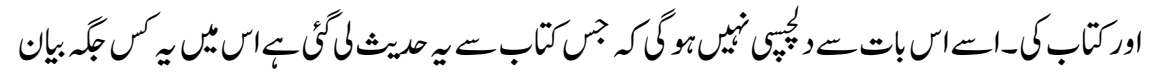
$20 "-\frac{\pi}{6}$

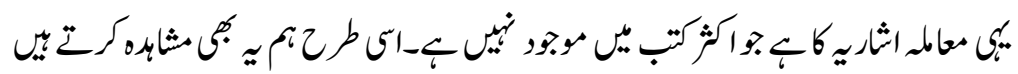

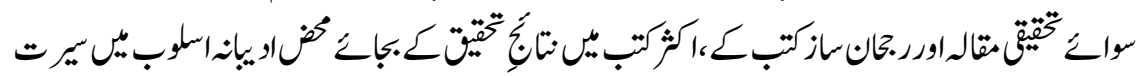

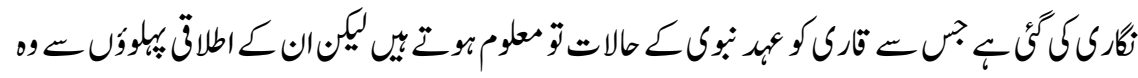

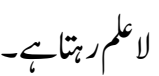




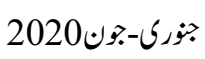

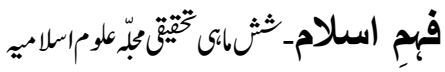

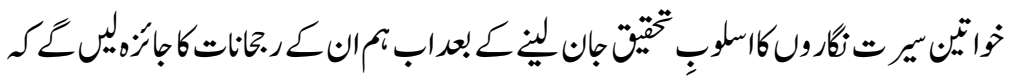

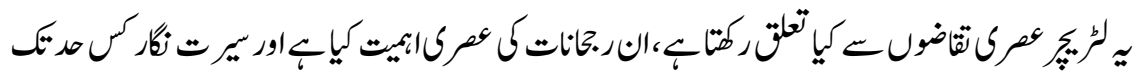

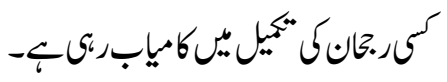

(2).

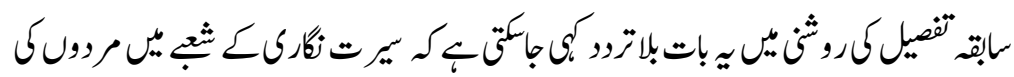

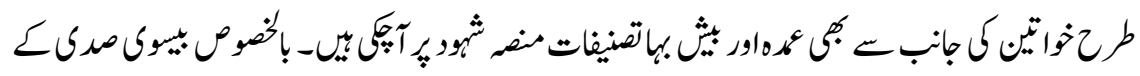

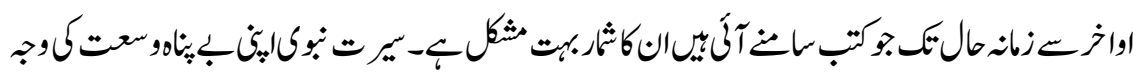

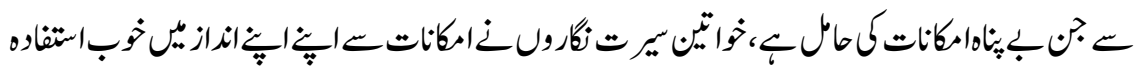

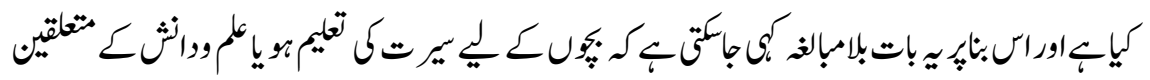

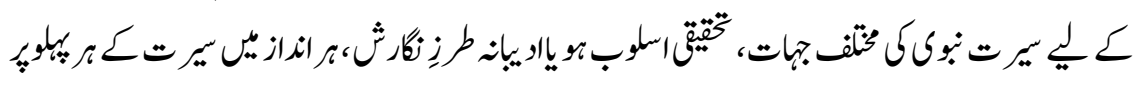

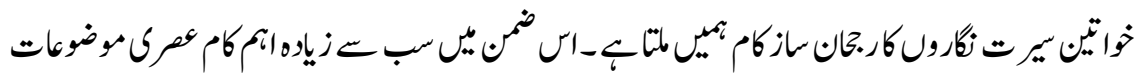

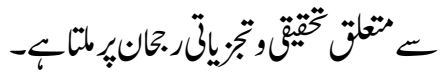

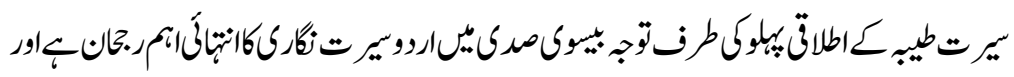

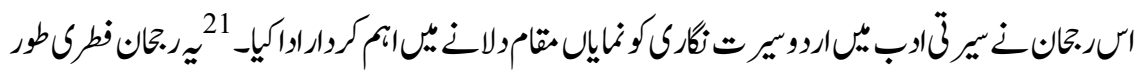

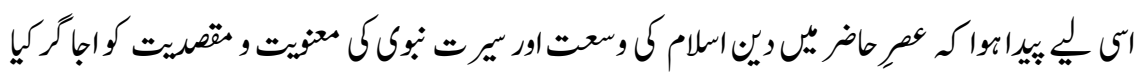

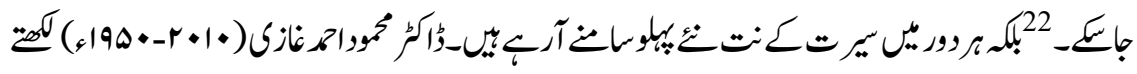

:

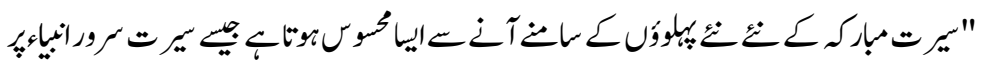

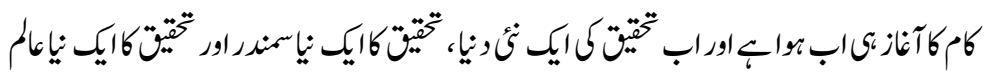
ريافت بوابك-"

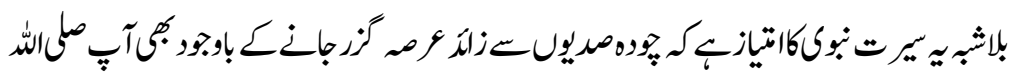

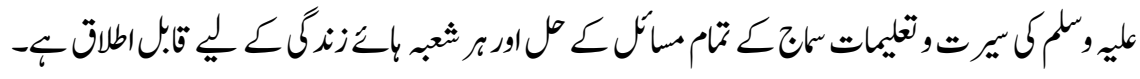

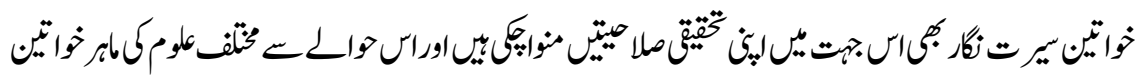

129 


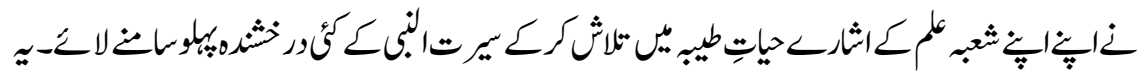

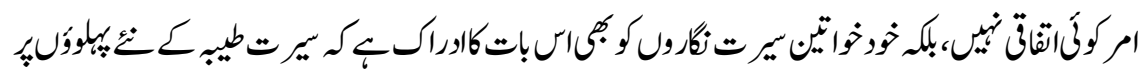

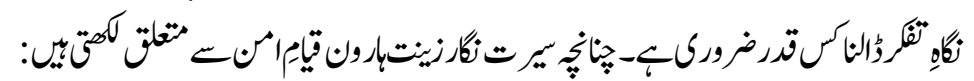

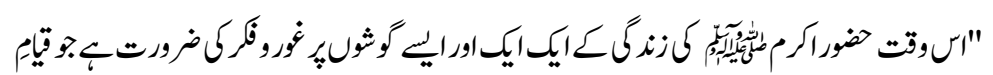

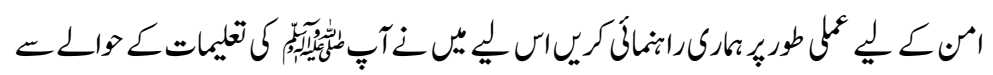

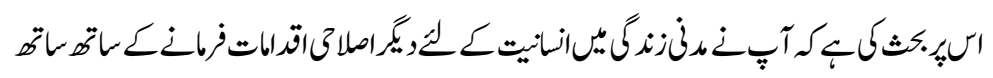

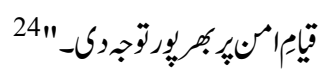

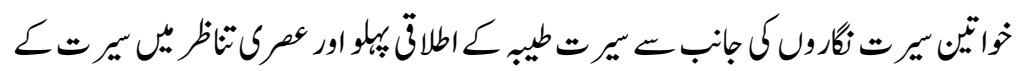

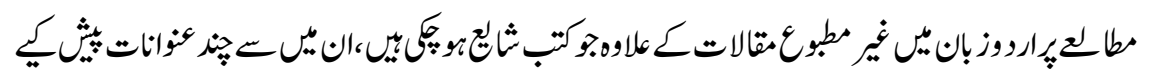
جإتبـ

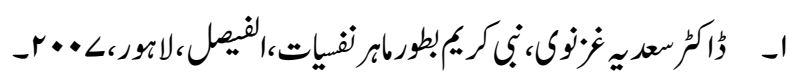

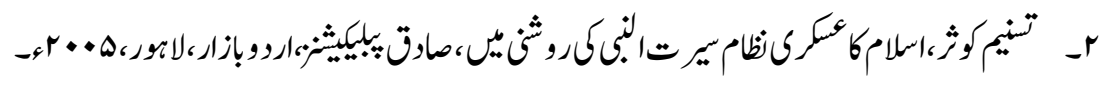

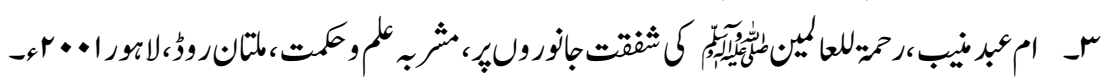

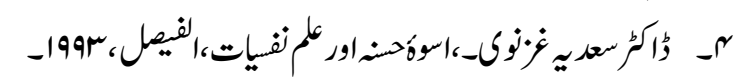

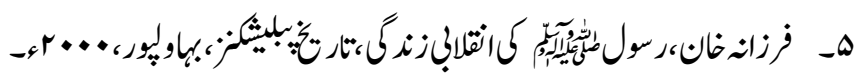

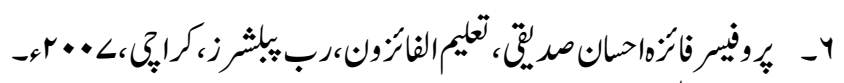

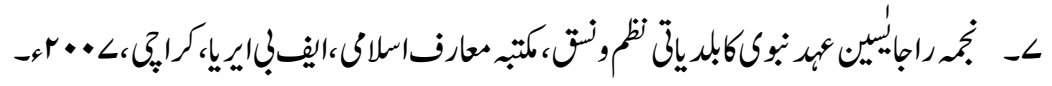

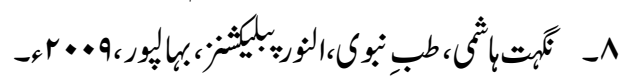

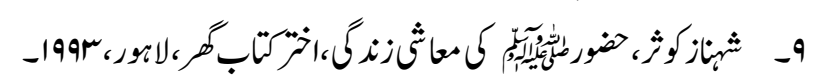

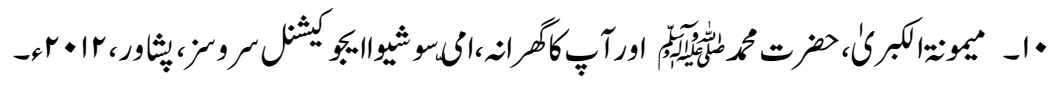

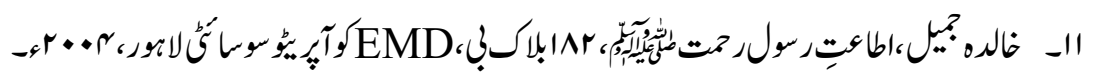

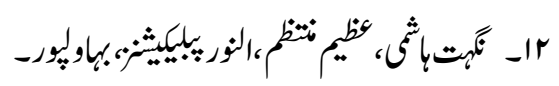

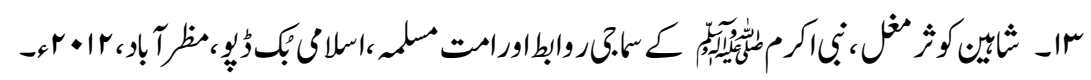




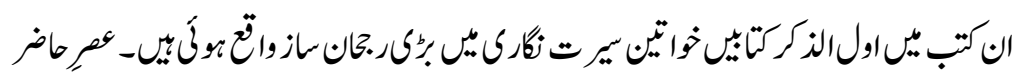

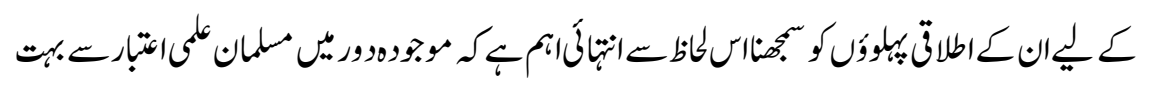

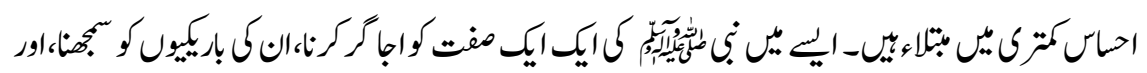

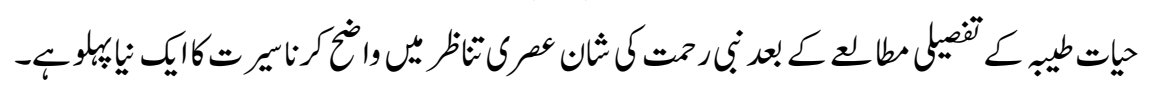

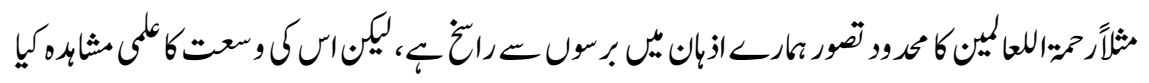

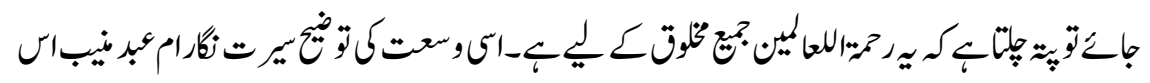

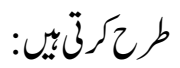

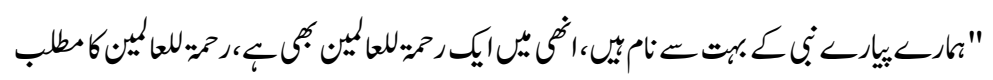

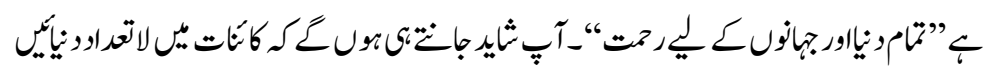

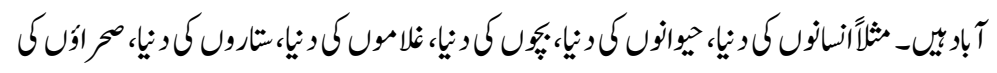

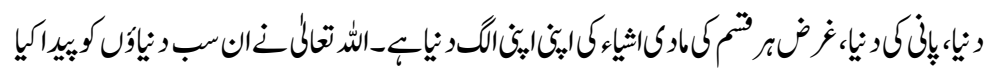

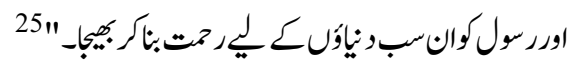

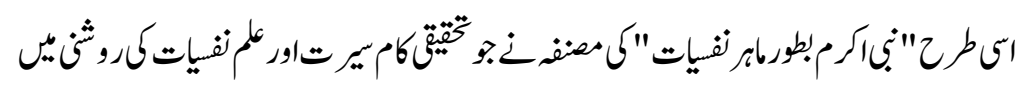

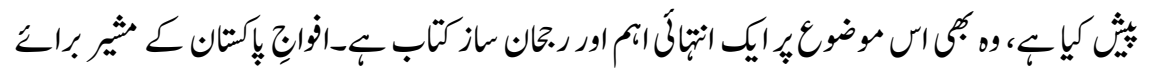

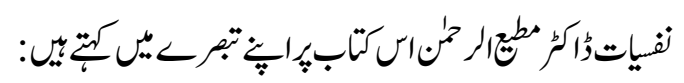

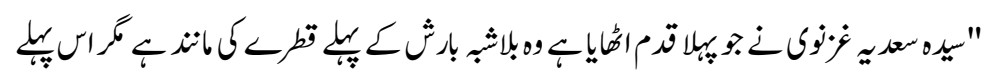

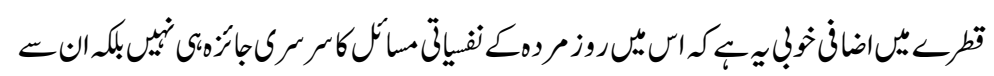

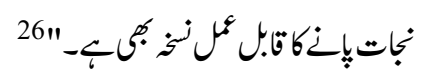

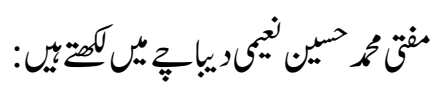

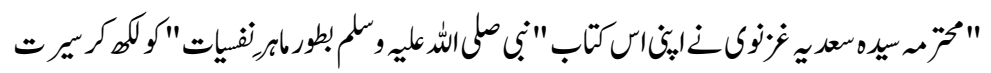

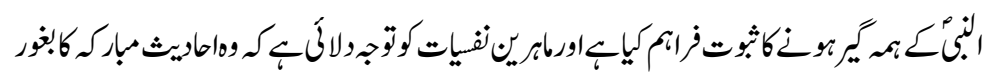

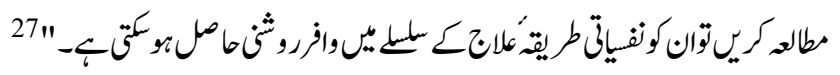




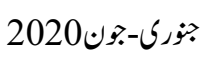

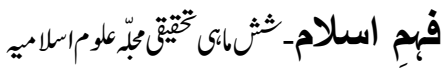

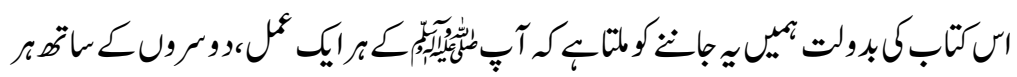

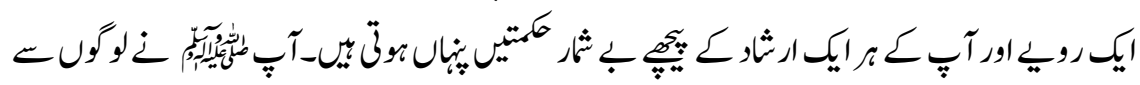

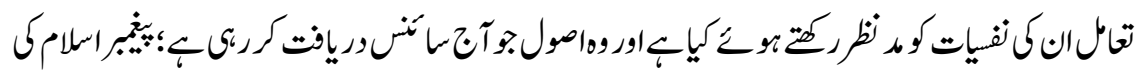

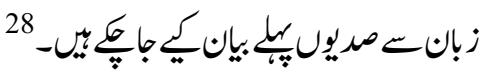

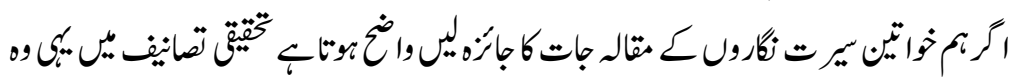

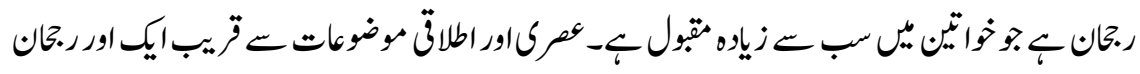

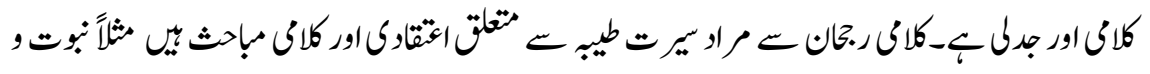

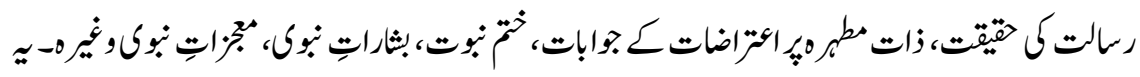

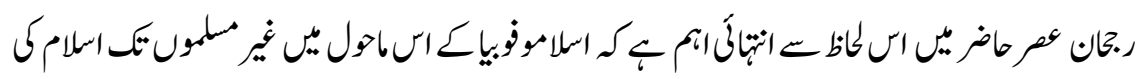

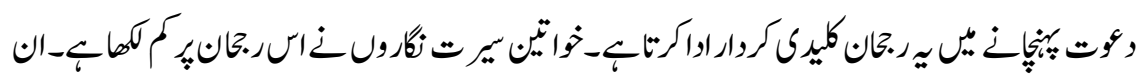

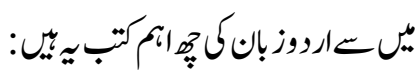

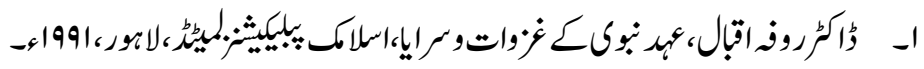

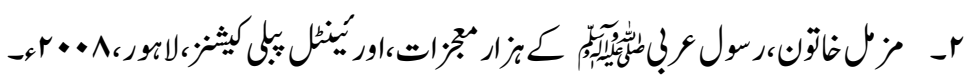

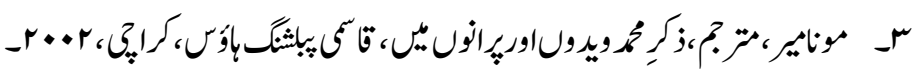

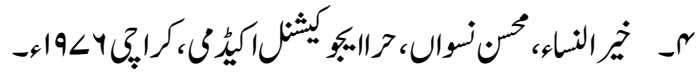

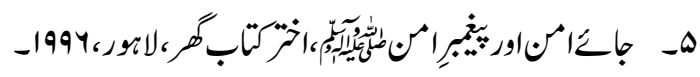

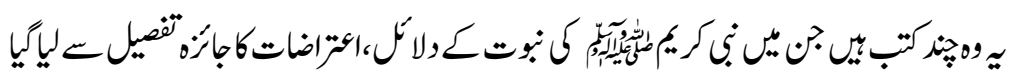

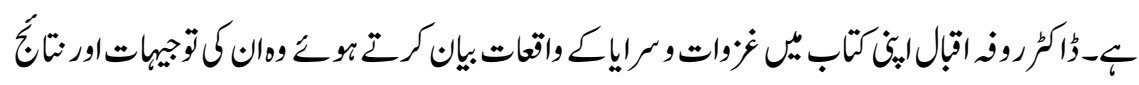

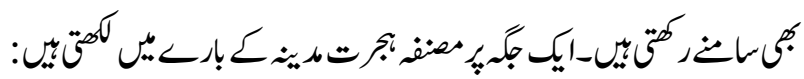

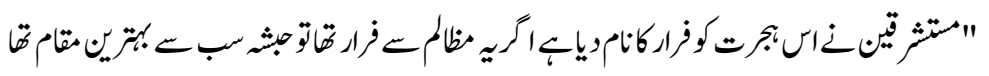

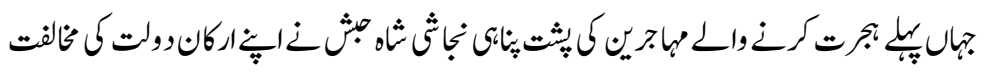

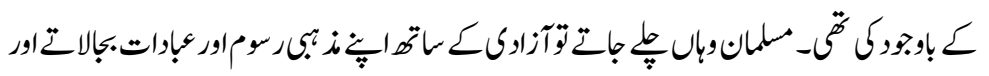

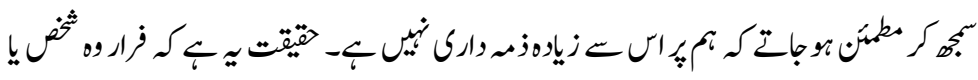

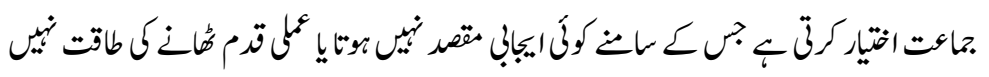

132 


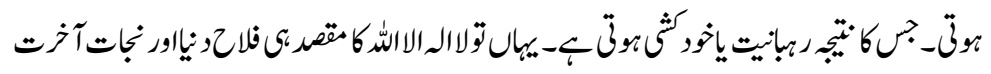

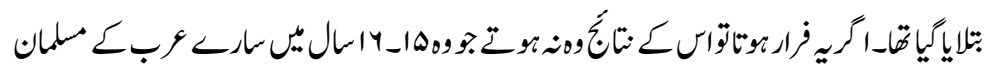

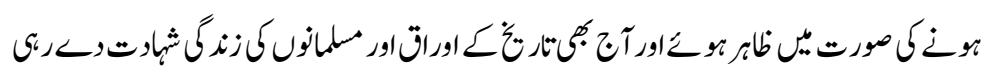

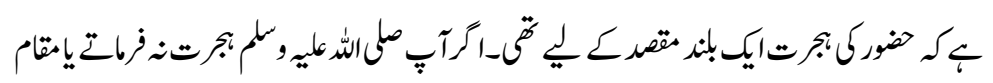

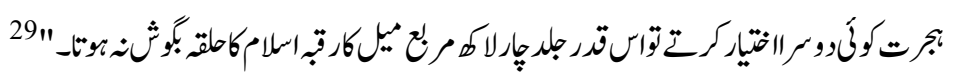

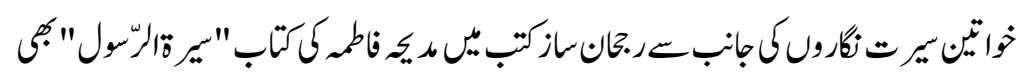

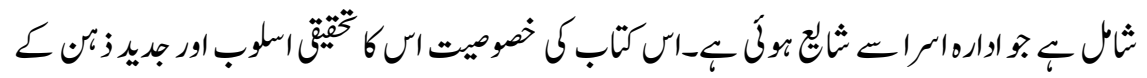

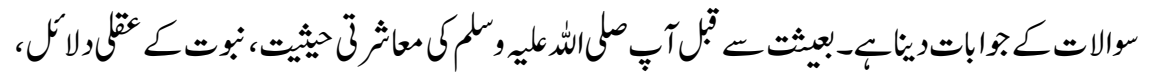

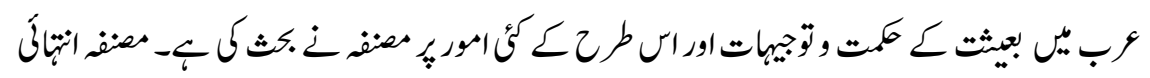

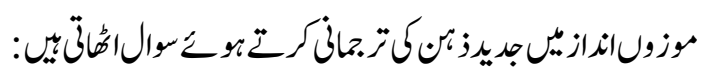

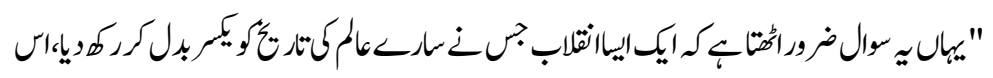

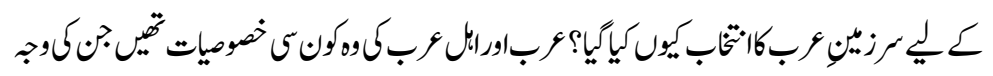

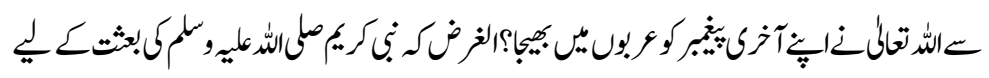

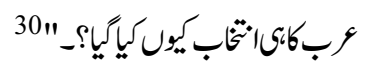

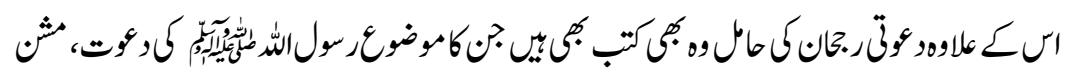

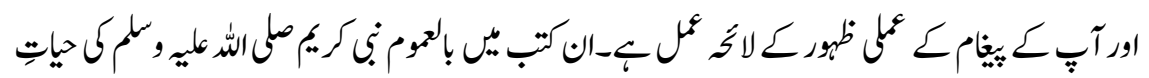

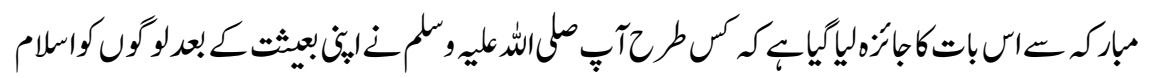

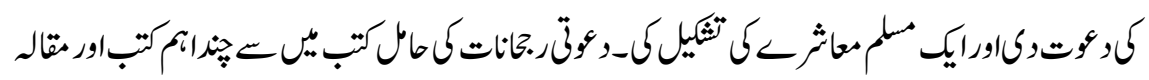
جاتييّي:

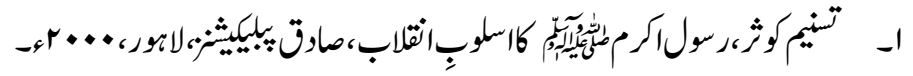

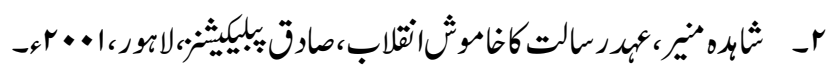

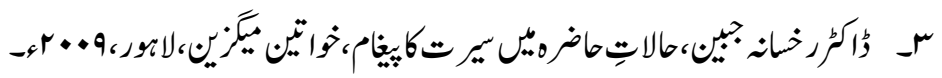




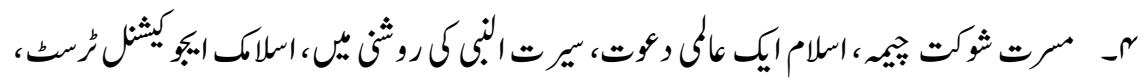

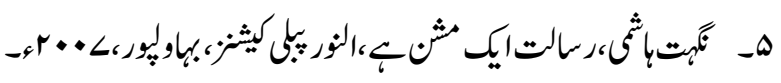

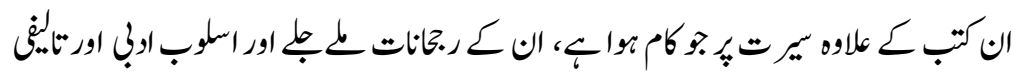

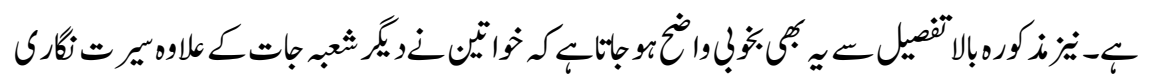

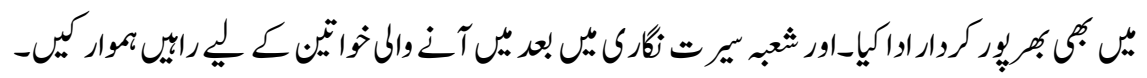

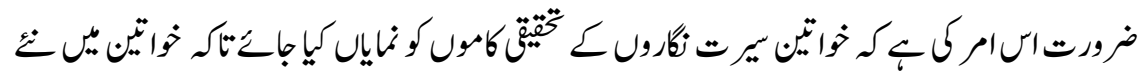

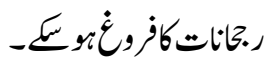

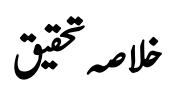

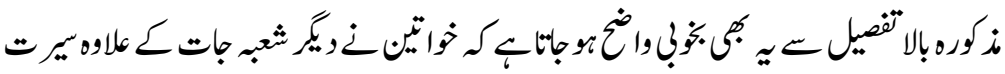

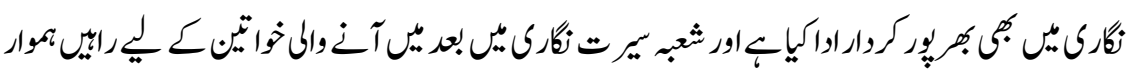

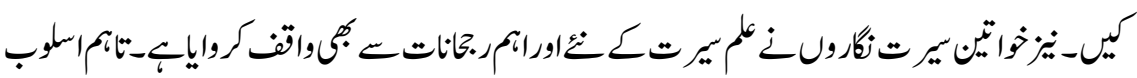

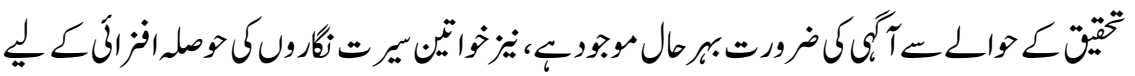

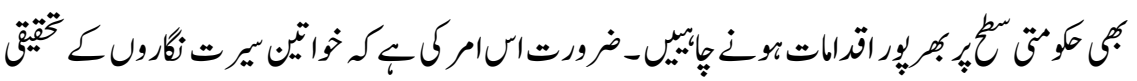

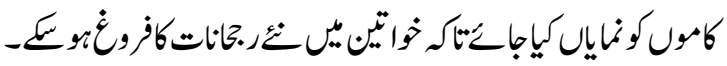

\section{حاثّىوحاله جات}

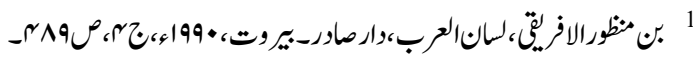

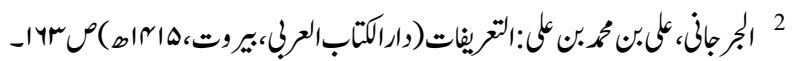

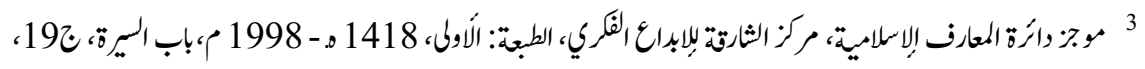
-6014

4

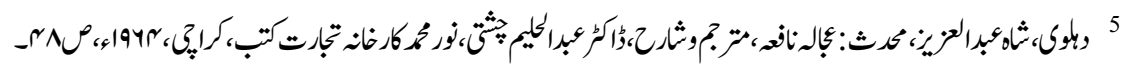




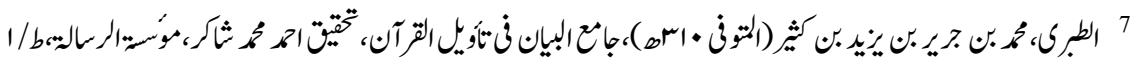

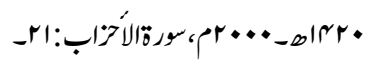
8

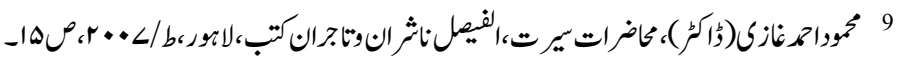

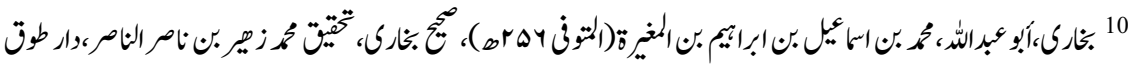

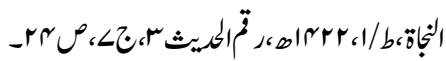

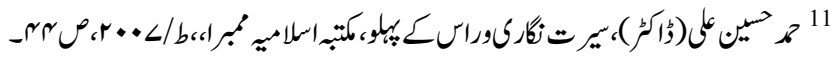
12

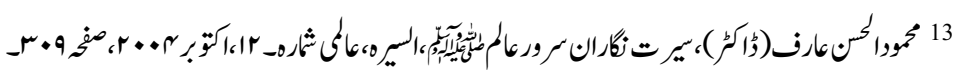

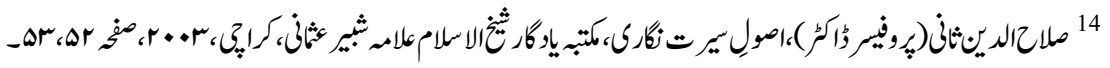

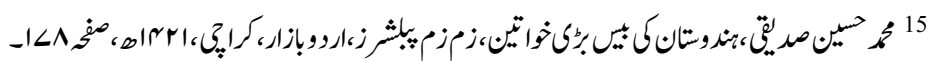

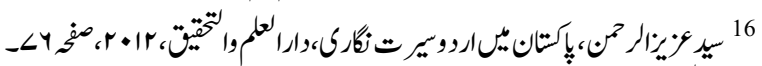

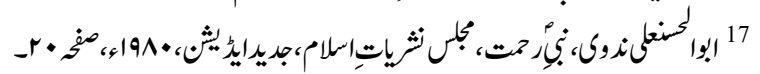

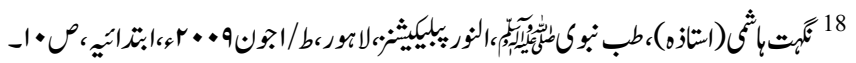

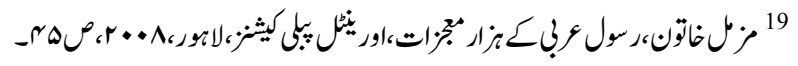
20

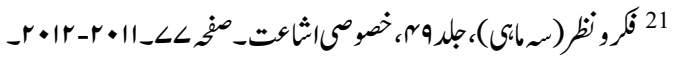

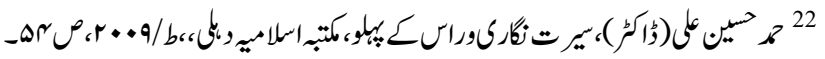

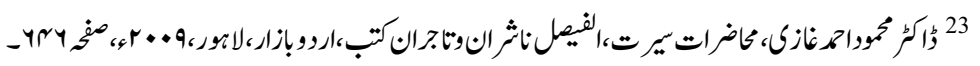

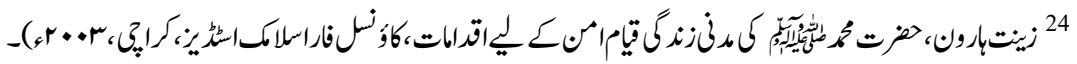

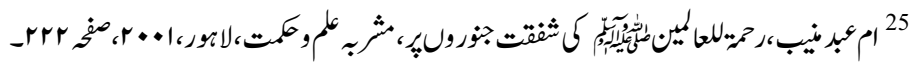

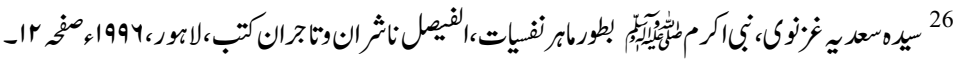

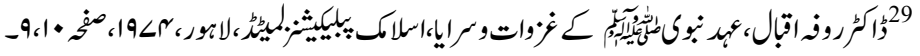

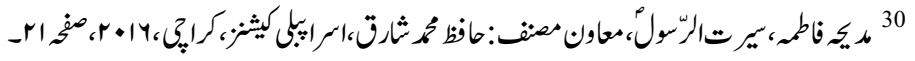

